\title{
Factors Predicting Non-Sentinel Lymph Node Involvement in Sentinel Node Positive Breast Carcinoma
}

\section{Sentinel Nod Pozitif Meme Karsinomunda Non-Sentinel Lenf Nodu Tutulumunu Öngören Faktörler}

\author{
Merih GÜRAY DURAK ${ }^{1}$, Bülent AKANSU², Mehmet Mustafa AKIN² , Ali İbrahim SEVINÇ³, \\ Mehmet Ali KOÇDOR ${ }^{3}$, Serdar SAYDAM ${ }^{3}$, Ömer HARMANCIOĞLU ${ }^{3}$, Hülya ELLIDOKUZ ${ }^{4}$, Recep BEKiş̧, \\ Tülay CANDA ${ }^{1}$
}

Departments of ${ }^{1}$ Pathology, ${ }^{3}$ General Surgery, ${ }^{5}$ Nuclear Medicine, Dokuz Eylül University, Faculty of Medicine, IZMiR, TURKEY,

${ }^{2}$ Department of Pathology, Mustafa Kemal University, Faculty of Medicine, HATAY, TURKEY,

${ }^{4}$ Department of Preventive Oncology, Dokuz Eylül University, Oncology Institute, IZMIR, TURKEY

\begin{abstract}
Objective: In routine practice, axillary lymph node dissection is performed in early invasive breast cancer patients with positive sentinel node biopsy. However, sentinel node is the only involved axillary node in $40-70 \%$ of patients, and determining factors that predict axillary non-sentinel node involvement will therefore prevent unnecessary axillary lymph node dissection and decrease morbidity.

Material and Method: In this study, 119 invasive breast cancer patients with sentinel node metastasis who underwent axillary lymph node dissection between 1998-2009 at our institution were studied. Primary tumor characteristics and features of the metastatic tumors in sentinel nodes, such as microanatomic location, size of metastasis, and the ratio of metastatic tumor area to the total sentinel node area were evaluated. Student's t-test and multivariate logistic regression were used for statistical analysis.
\end{abstract}

Results: The mean age of the patients was 50.7 years (28-80). Forty-three patients (36\%) had invasive ductal and 25 patients $(21 \%)$ had invasive lobular carcinoma. Most of the patients had either pT1 $(44 \%)$ or pT2 (54\%) tumors. Fifty-four patients (45\%) had no further positive nodes in the axilla. The metastatic deposits in the sentinel node were subcapsular in 16 patients $(13 \%)$. The percent area of sentinel node occupied by tumor $(\mathrm{p}<0.001)$, number of sentinel nodes $(\mathrm{p}=0.041)$, and microanatomic location of metastatic tumor $(\mathrm{p}=0.002)$ were significantly associated with non-sentinel node metastasis in univariate analysis. The percent area of sentinel node occupied by tumor $(\mathrm{p}<0.001)$ and number of sentinel nodes $(\mathrm{p}=0.033)$ remained significantly associated with non-sentinel node involvement in multivariate analysis.

Conclusion: In patients with invasive breast cancer and positive sentinel node, area percent of sentinel node occupied by tumor, and the number of sentinel nodes removed are independently predictive of non-sentinel node involvement.

Key Words: Breast cancer, Sentinel lymph node, Metastasis, Tumor load

Received : 26.04.2011

Accepted : 30.05.2011
ÖZ

Amaç: Rutin uygulamada, sentinel lenf nodu biyopsisi pozitif erken evre invaziv meme kanseri hastalarına aksiller lenf nodu diseksiyonu yapılmaktadır. Ancak hastaların \%40-70'inde sentinel lenf nodu tek metastatik aksiller lenf nodu olduğu için, aksiller non-sentinel nod tutulumunu öngören faktörlerin belirlenmesi, gereksiz aksiller diseksiyonu önleyip morbiditeyi azaltacaktır.

Gereç ve Yöntem: Bu çalışmaya, 1998-2009 yılları arasında sentinel lenf nodu metastazı olup hastanemizde aksiller diseksiyon uygulanan 119 meme kanseri hastası dahil edildi. Primer tümör özellikleri yanı sıra mikroanatomik yerleşim, metastaz boyutu, metastatik tümör alanının total sentinel lenf nodu alanına oranı gibi sentinel lenf nodlarındaki tümör metastazlarının özellikleri değerlendirildi. İstatistiksel analiz için student $\mathrm{t}$ testi ve çok değişkenli lojistik regresyon kullanıldı.

Bulgular: Hastaların ortalama yaşı 50.7 (28-80) olup, 43 hastanın (\%36) invaziv duktal, 25 hastanın (\%21) invaziv lobüler karsinom tanısı vardı. Hastaların çoğunda pT1 (\%44) ya da pT2 (\%54) tümör izlendi. Elli dört hastanın (\%45) aksillasında non-sentinel lenf nodu metastazı izlenmedi. On altı hastanın (\%13) sentinel lenf nodundaki metastatik odak subkapsüler yerleşimliydi. Tek yönlü analizde, metastatik tümör alanının total sentinel lenf nodu alanına oran $(\mathrm{p}<0.001)$, çıarılan toplam sentinel lenf nodlarının sayısı $(\mathrm{p}=0.041)$ ve metastatik tümörün mikroanatomik yerleşimi $(\mathrm{p}=0.002)$ non-sentinel lenf nodu tutulumu ile anlaml ilișki gösterdi. Çok değişkenli analizde ise, metastatik tümör alanının toplam sentinel lenf nodu alanına oranı $(\mathrm{p}<0.001)$ ile çıkarılan toplam sentinel lenf nodların sayısının ( $\mathrm{p}=0.033)$ non-sentinel lenf nodu tutulumu ile anlamlı ilişkisi devam etti.

Sonuç: Meme kanseri ve pozitif sentinel lenf nodu olan hastalarda, sentinel lenf nodunun tümör ile kaplı olan alanı yanı sıra çıkarılan sentinel lenf nodların sayısı non-sentinel lenf nodu tutulumu açısından bağımsız göstergelerdir.

Anahtar Sözcükler: Meme kanseri, Sentinel lenf nodu, Metastaz, Tümör yükü

Correspondence: Merih GÜRAY DURAK

Department of Pathology, Dokuz Eylül University, Faculty of Medicine, IZMIIR, TURKEY

E-mail: merih.guray@deu.edu.tr Phone: +902324123401 


\section{INTRODUCTION}

The most important prognostic factor in primary invasive breast cancer is the status of the axillary lymph nodes. Sentinel lymph node (SN) biopsy has become the routine surgical procedure for axillary nodal staging, particularly in patients with early-stage invasive breast cancer. Currently, axillary lymph node dissection (ALND) is performed only in patients with positive SN. However, it is well known that the SN is the only involved axillary node in $40-70 \%$ of patients (1-4). Moreover, the therapeutic effect of axillary radiation therapy and systemic chemotherapy in patients with metastatic SN also questions the true benefit of ALND that has many morbidities for the patient $(2,5)$.

Primary tumor size, presence of peritumoral lymphovascular invasion, size of the SN metastasis, number of positive SNs, the ratio of positive SNs to all identified SNs, and extracapsular extension have been reported to be strongly associated with non-SN status (1,6-10). However, none of these factors alone have been proven to be helpful in distinguishing patients who are suitable or not for further ALND. Although a number of scoring systems and nomograms, that predict non-SN status in patients with invasive breast cancer and SN metastasis have been developed, these prediction models need to be validated before being used in routine practice $(6,11-13)$.

In our study, we reviewed the slides of patients with invasive breast cancer who have positive SNs, with the aim of determining whether micromorphometric features and tumor load of positive SNs are useful for predicting non-SN status in early breast cancer patients. We also evaluated the correlation of primary tumor characteristics with non-SN metastasis in these patients.

\section{MATERIAL and METHOD}

One hundred and nineteen invasive breast cancer patients with a positive SN biopsy, who underwent subsequent ALND at Dokuz Eylul University Faculty of Medicine, between January 1998 and December 2009, were included in this study. The original hematoxylin-eosin (H\&E) slides and pathology reports were reviewed for primary tumor size, histologic type of tumor, and presence of peritumoral lymphovascular invasion.

SN biopsy was performed with radioisotope and/or blue dye injection, as previously described (6). SNs were bisected if less than $5 \mathrm{~mm}$ or sliced at 2-3 $\mathrm{mm}$ intervals if greater than $5 \mathrm{~mm}$. ALND was performed in patients with positive SNs diagnosed with cytology imprint and/or frozen section. The number of SNs removed and number of positive SNs were recorded. SNs were examined by both conventional histology and immunohistochemistry (IHC). IHC was performed with cytokeratin AE1/AE3 (Dako, Glostrup, Denmark). The microanatomic location of metastatic deposits within each $\mathrm{SN}$ was classified as subcapsular, parenchymal, combined subcapsular and parenchymal (single focus), multifocal or extensive (14). Multifocality was defined as two or more separated metastatic deposits at some distance from each other, whereas extensive SN involvement was defined as any metastasis $>5 \mathrm{~mm}$ in diameter, or any node with extracapsular spread $(14,15)$.

The largest diameter of the metastasis in each SN was measured from the slide with an ocular micrometer. If more than one deposit of tumor was found in a $\mathrm{SN}$, or if multiple SNs were positive, the size of the largest tumor deposit was recorded. The size of the tumor was classified according to the International Union Against Cancer (UICC) classification as follows: isolated tumor cells (solitary tumor cells or tumor cell clusters with a size of 0.2 $\mathrm{mm}$ or less), micrometastasis (tumor with a size of $0.2-2$ $\mathrm{mm}$ ), and macrometastasis (tumor greater than $2 \mathrm{~mm}$ in size) (16).

The area of metastatic tumor was calculated by multiplying the largest two dimensions of the tumor. In cases with more than one metastatic focus, the area of each focus was measured separately and were added to each other. The surface area of each lymph node was calculated by multiplying the largest two dimensions of the lymph node. The ratio of the total metastatic tumor area to the largest surface area of the lymph node was multiplied by 100 , and the percentage of area replaced by tumor was obtained.

The relationship between positivity of non-SN and the predictive factors was assessed using Pearson chi-square test for categorical variables. Characteristics that were found to be significant by univariate analysis were then entered in a backward stepwise method in a logistical regression analysis to develop a multivariate model of independent factors, for predicting the presence of positive non-SNs. All statistical analyses were performed using SPSS for Windows 11.0. $\mathrm{P}$ values of $\leq 0.05$ were considered to be statistically significant.

\section{RESULTS}

A total of 119 female patients with primary invasive breast cancer and SN metastasis were analyzed in this study. Patient and tumor characteristics are shown in Table I. The mean age of the patients was 50.7 years (range, 28-80 years). Histological type of the primary tumor was invasive ductal carcinoma in 43 patients (36.1\%), invasive lobular carcinoma in 25 patients (21.0\%), and mixed invasive breast carcinoma in 51 patients (42.9\%). The majority of the patients $(90.8 \%)$ had peritumoral lymphovascular invasion. The size of the primary tumor was calculated 
Table I: Clinicopathologic characteristics of invasive breast cancer patients with a positive $\mathrm{SN}$

\begin{tabular}{|l|c|}
\hline Characteristics & No. (\%) \\
\hline All cases & 119 \\
\hline Mean age, years (S.D) & $50.7(11.5)$ \\
\hline Mean tumor size, mm (S.D) & $21.6(9.8)$ \\
\hline pT1 & $53(44.6)$ \\
\hline pT2 & $64(53.8)$ \\
\hline pT3 & $1(0.8)$ \\
\hline pT4 & $1(0.8)$ \\
\hline Histological subtype & \\
\hline Invasive ductal carcinoma & $43(36.1)$ \\
\hline Invasive lobular carcinoma & $25(21.0)$ \\
\hline Mixed invasive breast carcinoma & $51(42.9)$ \\
\hline Lymphovascular invasion & \\
\hline Yes & $108(90.8)$ \\
\hline No & $9(7.7)$ \\
\hline
\end{tabular}

* Lymphovascular invasion could not be determined in 2 outside patients

SN: sentinel lymph node

in 104 patients $(87.4 \%)$, whereas in 15 consultation cases (12.6\%) with outside excision, the exact size of the primary tumor could not be obtained. The mean size of the primary tumor in 104 patients was $21.6 \mathrm{~mm}$ (range, 2-54 mm). There was no significant statistical correlation between age of the patients $(\mathrm{p}=0.676)$, histological type $(\mathrm{p}=0.277)$ and size of the primary tumor $(\mathrm{p}=0.931)$ and the presence of non-SN metastasis.

Most cases were either pT1 (53 patients, $44.5 \%$ ) or pT2 (64 patients, 53.8\%). Non-SN metastasis was detected in 27 patients (41.5\%) with pT1 and 36 patients $(55.5 \%)$ with pT2 tumor. There was no statistically significant difference between these two groups in terms of non-SN metastasis $(\mathrm{p}=0.582)$. There was 1 patient $(1.5 \%)$ with $\mathrm{pT} 3$, and 1 patient (1.5\%) with pT4 tumor who had non-SN metastasis.

SN biopsy was performed in all patients. SN and non-SN characteristics of the patients are listed in Table II. The total number of SNs per patient varied from 1 to 7 . The number of metastatic SNs per patient ranged from 1 to 4 . Sixty-five patients $(54.6 \%)$ had metastatic tumor in the non-SNs, whereas in 54 patients (45.4\%) there was no metastasis in the non-SNs. The mean number of non-SNs obtained with axillary dissection per patient was 14.6 (range, 1-29). The number of metastatic non-SNs per patient ranged from 1 to 18 .
Features of the metastatic tumor in the SNs, such as the microanatomic location and size of the tumor, and the ratio of the metastatic tumor area to the total lymph node area were evaluated. The metastatic deposits were subcapsular in 16 patients $(13.4 \%)$, parenchymal in 10 patients $(8.4 \%)$, subcapsular and parenchymal as a single focus in 25 patients (21.0\%), multifocal in 25 patients (21.0\%), and extensive in 43 patients (36.1\%) (Figures 1-5).

Two patients $(1.7 \%)$ had isolated tumor cell clusters $(<0.2$ $\mathrm{mm})$ in the SNs, 14 patients $(11.8 \%)$ had micrometastasis $(0.2-2 \mathrm{~mm})$, and 103 patients $(86.6 \%)$ had macrometastasis ( $>2 \mathrm{~mm}$ ). In 46 patients (38.7\%) the metastatic tumor load in the SNs was $\leq 25 \%$, in 20 patients (16.8\%) it was between $26-50 \%$, and in 53 patients $(44.5 \%)$ the tumor load was $>50 \%$.

In univariate analysis, the microanatomic location of $\mathrm{SN}$ metastasis correlated significantly with non-SN inolvement $(\mathrm{p}=0.002)$. Patients with subcapsular, parenchymal, combined subcapsular and parenchymal, multifocal, and extensive tumor deposits showed non-SN involvement in $12.3 \%, 3.1 \%, 20.0 \%, 13.8 \%$, and $50.8 \%$ of the cases, respectively. The ratio of metastatic tumor area to the total

Table II. Sentinel and non-sentinel lymph node characteristics of invasive breast cancer patients with a positive SN and ALND

\begin{tabular}{|l|c|}
\hline Characteristics & No. (\%) \\
\hline Total number of SNs & 248 \\
\hline Mean number of SNs (S.D) & $2.1(1.2)$ \\
\hline Total number of positive SNs (range) & $167(1-4)$ \\
\hline Mean number of non-SNs (S.D) & $14.6(5.6)$ \\
\hline Total number of positive non-SNs (range) & $258(1-18)$ \\
\hline $\begin{array}{l}\text { Mean area \% of SN occupied by tumor } \\
\text { (S.D) }\end{array}$ & $48.6(37.4)$ \\
\hline Size of metastatic tumor in SNs & $2(1.7)$ \\
\hline Isolated tumor cells & $14(11.8)$ \\
\hline Micrometastases & $103(86.5)$ \\
\hline Macrometastases & $16(13.4)$ \\
\hline $\begin{array}{l}\text { Microanatomic location of metastatic } \\
\text { tumor in SNs }\end{array}$ & $10(8.4)$ \\
\hline Subcapsular & $25(21.0)$ \\
\hline Parenchymal & $25(21.0)$ \\
\hline $\begin{array}{l}\text { Subcapsular and parenchymal (single } \\
\text { focus) }\end{array}$ & $43(36.1)$ \\
\hline Multifocal & \\
\hline Extensive &
\end{tabular}

SN: sentinel lymph node, ALND: axillary lymph node dissection 


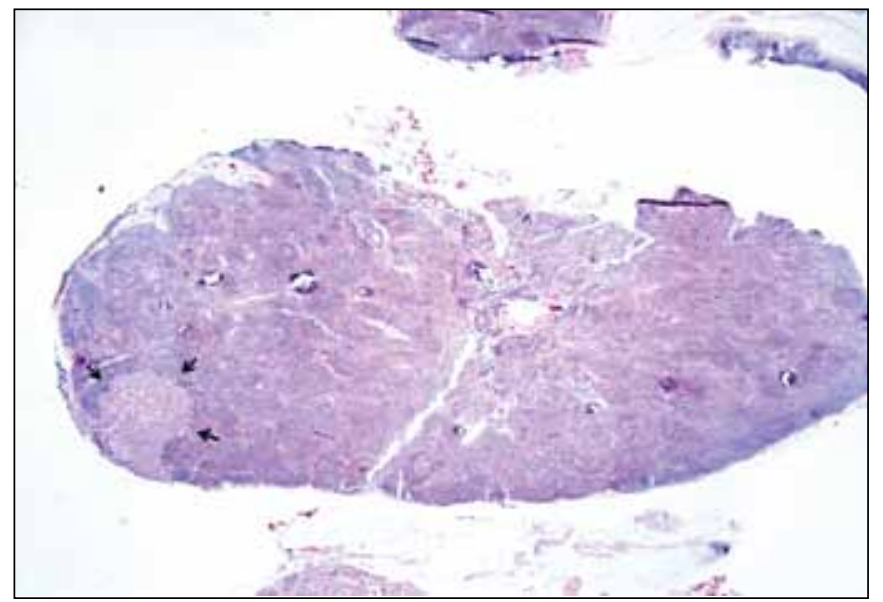

Figure 1: Subcapsular tumor metastasis in a sentinel lymph node (H\&E; $\mathrm{x} 20)$.

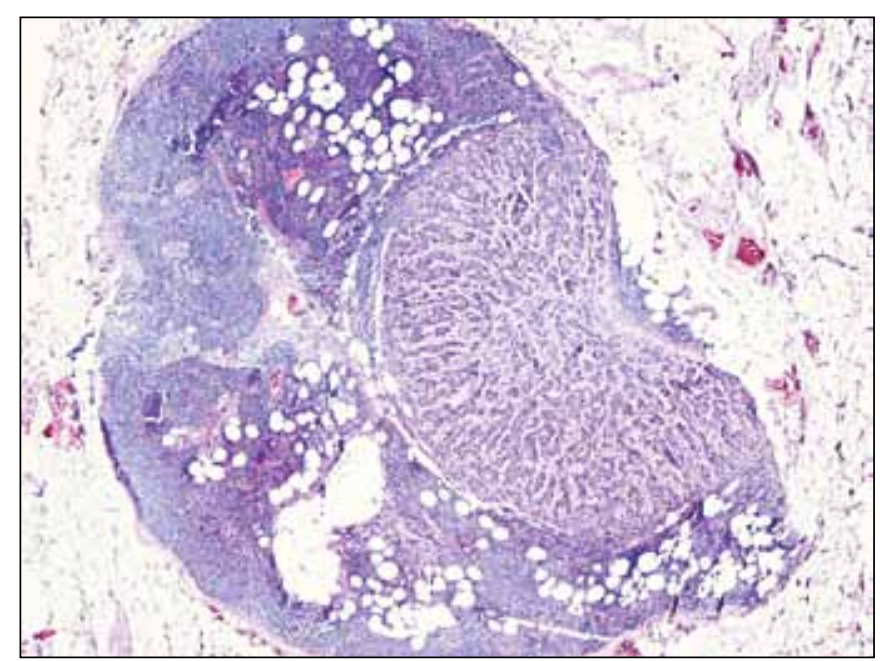

Figure 3: Subcapsular and parenchymal tumor metastasis as a single focus in a sentinel lymph node (H\&E; x20).

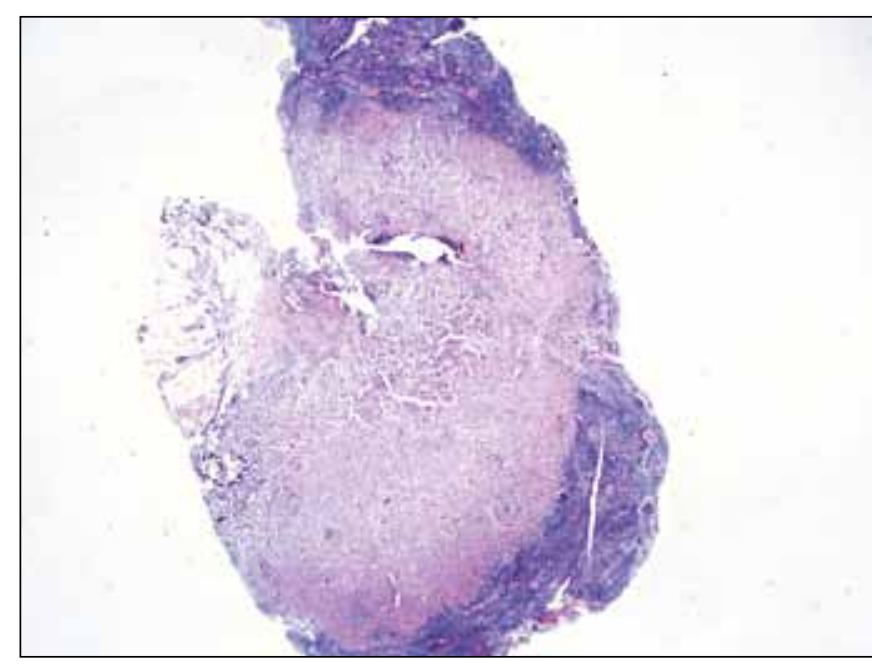

Figure 5: Extensive tumor metastasis in a sentinel lymph node (H\&E; $\mathrm{x} 20)$.

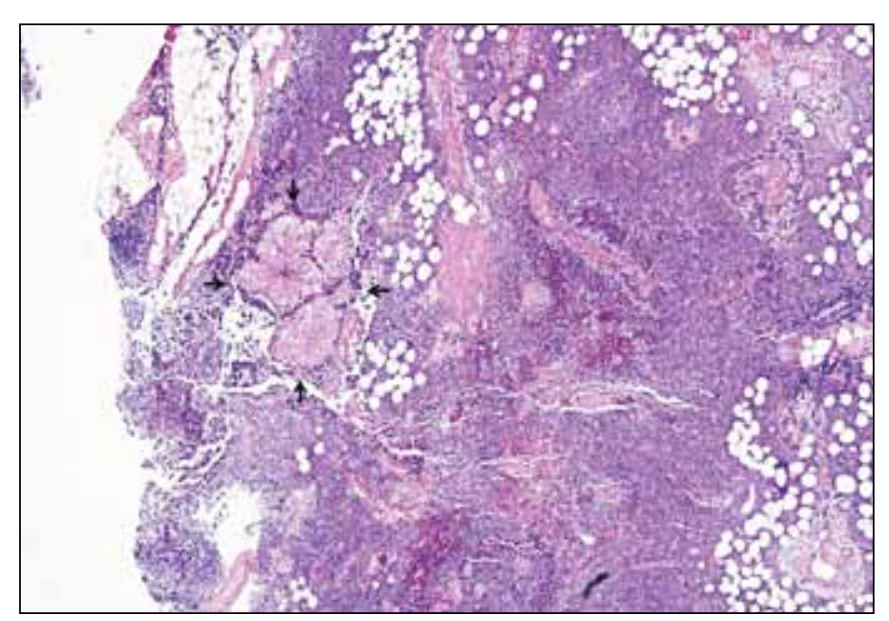

Figure 2: Parenchymal tumor metastasis in a sentinel lymph node (H\&E; $\mathrm{x} 20)$.

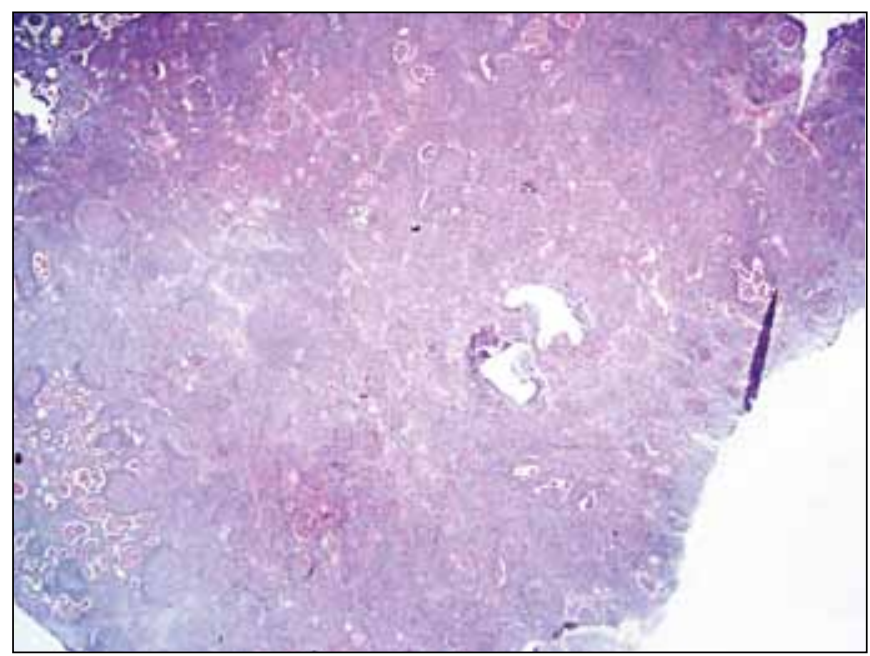

Figure 4: Multifocal tumor metastasis in a sentinel lymph node (H\&E; $\mathrm{x} 20)$.

$\mathrm{SN}$ area $(\mathrm{p}<0.001)$, and the total number of SNs removed $(\mathrm{p}=0.041)$ were also significantly associated with the presence of metastasis in the non-SNs. The tumor load in the SNs was $\leq 25 \%$ in 31 patients (57.4\%) with no further metastasis in the non-SNs, whereas 40 patients $(61.5 \%)$ with metastasis in the non-SNs had tumor load $>50 \%$ in the SNs. Patients were further grouped into two, as patients in whom only one $\mathrm{SN}$ was removed, as opposed to those with more than one SN removed; $68.8 \%$ of patients with only one $\mathrm{SN}$ removed had nodal metastases in non-SNs, versus $45.1 \%$ of those with multiple $\mathrm{SNs}$ resected $(\mathrm{p}=0.015)$.

In multivariate analysis, the ratio of metastatic tumor area to the total $\mathrm{SN}$ area, ie. the area percent of $\mathrm{SN}$ occupied by tumor $(\mathrm{p}<0.001)$, and the number of total SNs removed $(\mathrm{p}=0.033)$ remained significantly associated with non$\mathrm{SN}$ involvement. Table III summarizes the results of the 
Table III: Correlation between clinicopathologic features and positive non-SNs

\begin{tabular}{|c|c|c|c|c|}
\hline Tumor characteristics & $\mathbf{N}$ & $\begin{array}{l}\% \text { patients with } \\
\text { positive non-SN }\end{array}$ & $\begin{array}{l}\text { P value, } \\
\text { univariate }\end{array}$ & $\begin{array}{c}\text { P value, } \\
\text { multivariate }\end{array}$ \\
\hline Histological subtype & & & 0.277 & \\
\hline Invasive ductal & 43 & 30.8 & & \\
\hline Invasive lobular & 25 & 20.0 & & \\
\hline Mixed breast $\mathrm{Ca}$ & 51 & 49.2 & & \\
\hline Stage & & & 0.582 & \\
\hline pT1 & 53 & 41.5 & & \\
\hline pT2 & 64 & 55.4 & & \\
\hline pT3 & 1 & 1.5 & & \\
\hline pT4 & 1 & 1.5 & & \\
\hline $\mathrm{LVI}^{*}$ & & & 1.000 & \\
\hline Yes & 108 & 92.3 & & \\
\hline No & 9 & 7.7 & & \\
\hline Microanatomic location & & & 0.002 & \\
\hline Subcapsular & 16 & 12.3 & & \\
\hline Parenchymal & 10 & 3.1 & & \\
\hline Single focus ${ }^{* *}$ & 25 & 20.0 & & \\
\hline Multifocal & 25 & 13.8 & & \\
\hline Extensive & 43 & 50.8 & & \\
\hline Size of metastatic tumor & & & 0.312 & \\
\hline ITH $(<0.2 \mathrm{~mm})$ & 2 & 1.5 & & \\
\hline $0.2-2 \mathrm{~mm}$ & 14 & 7.7 & & \\
\hline$>2 \mathrm{~mm}$ & 103 & 90.8 & & \\
\hline Area \% of SN occupied by tumor & & & $<.001$ & $<0.001$ \\
\hline$\leq 25 \%$ & 46 & 23.1 & & \\
\hline $26-50 \%$ & 20 & 15.4 & & \\
\hline$>50 \%$ & 53 & 61.5 & & \\
\hline
\end{tabular}

LVI, lymphovascular invasion; ITH, isolated tumor cells; SN, sentinel lymph node.

${ }^{\star}$ Lymphovascular invasion could not be determined in 2 outside patients.

${ }^{*}$ Combined subcapsular and parenchymal (single focus).

statistical analyses to determine the relationship between clinicopathologic variables and positive non-SNs.

\section{DISCUSSION}

Our findings indicate that the area percent of SN occupied by tumor, and the total number of SNs removed predict the presence of non-SN metastasis in patients with invasive breast cancer. The size of the metastatic tumor in SNs has been proven to be a predictor of non-SN involvement by many studies using multivariate analyses $(6,7,15,17,18)$. Other factors considering tumor burden in SNs, such as percent replacement of $\mathrm{SN}$ by tumor, the number of positive SNs, the proportion of involved SNs among all identified
SNs, and presence of extracapsular extension have also been shown to be predictors of non-SN involvement by different studies (2,8,10-12,17,19-22). These findings have encouraged researchers to find out simple methods to evaluate the tumor burden in SNs. Farshid et al. were the first to consider the proportion of SN replaced by metastasis (23). They have found out that proportion of SN replaced by metastasis, as well as the age of the patient and the number of SNs were independent predictors of non-SN status. Van Deurzen et al., on the other hand, have used morphometric analysis in order to accurately assess the tumor load in SNs, and have reported that the frequency of second echelon lymph node metastases in patients with area 
percent of SN occupied by tumor $<6 \%$, between $6-80 \%$, and $>80 \%$ was $20 \%, 46 \%$, and $75 \%$, respectively (22). They have emphasized that no subgroup of patients could be identified with less than $20 \%$ of non-SN involvement, concluding that the area percent of SN occupied by tumor was the only independent factor in predicting second echelon lymph node involvement $(\mathrm{p}<0.001)(22)$.

In the present study, the area percent of SN occupied by tumor was $\leq 25 \%$ in 46 patients $(38.7 \%)$. The majority of these patients $(67.4 \%)$ did not have metastasis in their non-sentinel axillary lymph nodes. On the other hand, 40 (75.5\%) of 53 patients with a tumor burden $>50 \%$ in $\mathrm{SNs}$ had non-SN involvement $(\mathrm{p}<0.001)$. Patients with a tumor burden $\leq 25 \%$ were either pT1 $(50 \%)$ or pT2 $(50 \%)$. The only patients with pT3 and pT4 tumor had a tumor burden $>50 \%$ in their SNs. Although not statistically significant ( $\mathrm{p}=0.693$ ), this finding supports many studies that suggest size of primary tumor to be a positive predictor of non-SN involvement (1,24-26).

The number of total SNs removed as well as the number of positive and negative SNs have been evaluated by various studies $(6,15,17,22,23)$. Most studies have reported the number of positive SNs to be a positive predictor of nonSN involvement $(17,27,28)$. Goyal et al. have found that the difference in the number of positive and negative SNs removed, in addition to size of the $\mathrm{SN}$ metastasis were predictors of non-SN involvement (17). Barranger et al. have reported that the proportion of involved SNs among all identified SNs, as well as the primary tumor size and SN macrometastasis were independent predictors of non-SN metastasis (6). These studies all confirm that the increasing tumor burden in SNs is significantly associated with increasing likelihood of positive non-SNs. Farshid et al. have identified that, in addition to increasing proportion of SN replaced by metastasis and decreasing age, the total number of SNs resected was also an independent predictor of the status of non-SNs in SN positive patients (23). Our study, similar to Farshid et al's study, have demonstrated that patients with only one SN resected had a greater likelihood of non-SN involvement $(68.8 \%)$ compared to those with multiple SNs biopsied (45.1\%). According to Farshid et al., as more SNs are removed in the SN biopsy precedure, fewer nodes remain in the axilla which may harbour metastases (23).

In the present study, microanatomic location of metastasis in $\mathrm{SNs}(\mathrm{p}=0.002)$ was shown to be a significant positive predictor of residual axillary involvement, only with univariate analysis. Recently, some studies have reported significant correlation between microanatomic location of metastasis in SNs and non-SN involvement, both in breast cancer and malignant melanoma $(14,15,29)$. In this study, we generated 5 groups according to the microanatomic location of metastasis in SNs: subcapsular, parenchymal, subcapsular and parenchymal as a single focus, multifocal and extensive metastasis. Thirty-three out of 43 patients (76.7\%) with extensive SN metastasis had further axillary involvement, which is in accordance with van Deurzen et al's study (15).

Among studies that have reported significant correlation between size of metastasis in SNs and presence of non-SN involvement, the majority emphasizes that the chance of non-SN involvement decreases with the presence of isolated tumor cell clusters $(\leq 0.2 \mathrm{~mm})$ and/or micrometastasis $(0.2$ $2 \mathrm{~mm})(1,4,8,19)$. In our study, 1 of 2 patients with isolated tumor cells, and 5 of 14 patients with micrometastases had non-SN involvement $(\mathrm{p}=0.312)$. There are also studies that have investigated patients in whom ALND was not performed after finding micrometastasis in SNs, and they did not find any significant difference between patients, in terms of prognosis $(30,31)$. However, because up to $53 \%$ of patients with micrometastasis in SNs have nonSN metastasis, it is emphasized by van Deurzen et al., that macrometastases may arise in non-SNs of patients with micrometastasis or even isolated tumor cells in SNs (22).

In conclusion, increasing tumor burden in the $\mathrm{SNs}$ is a significant predictor of non-SN involvement. This study confirms that the area percent of SN occupied by tumor, as well as the total number of SNs excised are independent predictors of axillary metastasis. Further studies with larger patient populations are required to find out easier methods to evaluate the tumor burden in SNs accurately, and to detect distinct parameters which can spare patients who undergo ALND with no therapeutic benefit.

\section{REFERENCES}

1. Chu KU, Turner RR, Hansen NM, Brennan MB, Giuliano $A E$ : Sentinel node metastasis in patients with breast carcinoma accurately predicts immunohistochemically detectable nonsentinel node metastasis. Ann Surg Oncol 1999, 6:756-761

2. Turner RR, Chu KU, Qi K, Botnick LE, Hansen NM, Glass EC, Giuliano AE: Pathologic features associated with nonsentinel lymph node metastases in patients with metastatic breast carcinoma in a sentinel lymph node. Cancer 2000, 89:574-581

3. Kamath VJ, Giuliano R, Dauway EL, Cantor A, Berman C, $K u$ NN, Cox CE, Reintgen DS: Characteristics of the sentinel lymph node in breast cancer predict further involvement of higher-echelon nodes in the axilla: a study to evaluate the need for complete axillary lymph node dissection. Arch Surg 2001, 136:688-692

4. Abdessalam SF, Zervos EE, Prasad M, Farrar WB, Yee LD, Walker MJ, Carson WB, Burak WE Jr: Predictors of positive axillary lymph nodes after sentinel lymph node biopsy in breast cancer. Am J Surg 2001, 182:316-320 
5. Fisher B, Bryant J, Wolmark N, Mamounas E, Brown A, Fisher ER, Wickerham DL, Begovic M, DeCillis A, Robidoux A, Margolese RG, Cruz AB Jr, Hoehn JL, Lees AW, Dimitrov NV, Bear HD: Effect of preoperative chemotherapy on the outcome of women with operable breast cancer. J Clin Oncol 1998, 16: 2672-2685

6. Barranger E, Coutant C, Flahault A, Delpech Y, Darai E, Uzan S: An axilla scoring system to predict non-sentinel lymph node status in breast cancer patients with sentinel lymph node involvement. Breast Cancer Res Treat 2005, 91:113-119

7. Hwang RF, Krishnamurthy S, Hunt KK, Mirza N, Ames FC, Feig B, Kuerer HM, Singletary SE, Babiera G, Meric F, Akins JS, Neely J, Ross MI: Clinicopathologic factors predicting involvement of nonsentinel axillary nodes in women with breast cancer. Ann Surg Oncol 2003, 10:248-254

8. Viale G, Maiorano E, Pruneri G, Mastropasqua MG, Valentini S, Galimberti V, Zurrida S, Maisonneuve P, Paganelli G, Mazzarol G: Predicting the risk for additional axillary metastasis in patients with breast carcinoma and positive sentinel lymph node biopsy. Ann Surg 2005, 241:319-325

9. Chagpar AB, Scoggins CR, Martin RCG, Carlson DJ, Laidley AL, El-Eid SE, McGlothin TQ, McMasters KM: University of Louisville Breast Sentinel Lymph Node Study: prediction of sentinel lymph node-only disease in women with invasive breast cancer. Am J Surg 2006, 192:882-887

10. Stitzenberg KB, Meyer AA, Stern SL, Cance WG, Calvo BF, Klauber-DeMore N, Kim HJ, Sansbury L, Ollila DW: Extracapsular extension of the sentinel lymph node metastasis: a predictor of nonsentinel node tumor burden. Ann Surg 2003, 237:607-613

11. Van Zee KJ, Manasseh DM, Bevilacqua JL, Boolbol SK, Fey JV, Tan LK, Borgen PI, Cody HS 3rd, Kattan MW: A nomogram for predicting the likelihood of additional nodal metastases in breast cancer patients with a positive sentinel node biopsy. Ann Surg Oncol 2003, 10:1140-1151

12. Saidi RF, Dudrick PS, Remine SG, Mittal VK: Nonsentinel lymph node status after positive sentinel lymph node biopsy in early breast cancer. Am Surg 2004, 70:101-105

13. Coutant C, Olivier C, Lambaudie E, Fondrinier E, Marchal F, Guillemin F, Seince N, Thomas V, Levêque J, Barranger E, Darai E, Uzan S, Houvenaeghel G, Rouzier R: Comparison of models to predict nonsentinel lymph node status in breast cancer patients with metastatic sentinel lymph nodes: a prospective multicenter study. J Clin Oncol 2009, 27:2800-2808

14. Dewar DJ, Newell B, Green MA, Topping AP, Powell BW, Cook MG: The microanatomic location of metastatic melanoma in sentinel lymph nodes predicts nonsentinel lymph node involvement. J Clin Oncol 2004, 22:3345-3349

15. van Deurzen CHM, Seldenrijk CA, Koelemij R, van Hillegersberg R, Hobbelink MG, van Diest PJ: The microanatomic location of metastatic breast cancer in sentinel lymph nodes predicts nonsentinel lymph node involvement. Ann Surg Oncol 2008, 15:1309-1315

16. Connolly JL: Changes and problematic areas in interpretation of the AJCC Cancer Staging Manual, 6th edition, for breast cancer. Arch Pathol Lab Med 2006, 130:287-291

17. Goyal A, Douglas-Jones A, Newcombe RG, Mansel RE: ALMANAC Trialists Group: predictors of non-sentinel lymph node metastasis in breast cancer patients. Eur J Cancer 2004, 40:1731-1737

18. Bolster MJ, Peer PG, Bult P, Thunnissen FB, Schapers RF, Meijer JW, Strobbe LJ, van Berlo CL, Klinkenbijl JH, Beex LV, Wobbes T, Tjan-Heijnen VC: Risk factors for non-sentinel lymph node metastases in patients with breast cancer. The outcome of a multiinstitutional study. Ann Surg Oncol 2007, 14:181-189

19. Changsri C, Prakash S, Sandweiss L, Bose S: Prediction of additional axillary metastasis of breast cancer following sentinel lymph node surgery. Breast J 2004, 10:392-397

20. Joseph KA, El-Tamer M, Komenaka I, Troxel A, Ditkoff BA, Schnabel F: Predictors of nonsentinel node metastasis in patients with breast cancer after sentinel node metastasis. Arch Surg 2004, 139:648-651

21. Rivers AK, Griffith KA, Hunt KK, Degnim AC, Sabel MS, Diehl KM, Cimmino VM, Chang AE, Lucas PC, Newman LA: Clinicopathologic features associated with having four or more metastatic axillary nodes in breast cancer patients with a positive sentinel lymph node. Ann Surg Oncol 2006, 13:36-44

22. van Deurzen CH, van Hillegersberg R, Hobbelink MG, Seldenrijk CA, Koelemij R, van Diest PJ: Predictive value of tumor load in breast cancer sentinel lymph nodes for second echelon lymph node metastases. Cell Oncol 2007, 29:497-505

23. Farshid G, Pradhan M, Kollias J, Gill PG: A decision aid for predicting non-sentinel node involvement in women with breast cancer and at least one positive sentinel node. Breast 2004, 13:494-501

24. Cserni G: Sentinel lymph-node biopsy-based prediction of further breast cancer metastases in the axilla. Eur J Surg Oncol 2001, 27:532-538

25. Sachdev U, Murphy K, Derzie A, Jaffer S, Bleiweiss IJ, Brower S: Predictors of nonsentinel lymph node metastasis in breast cancer patients. Am J Surg 2002, 183:213-217

26. Wong SL, Edwards MJ, Chao C, Tuttle TM, Noyes RD, Woo C, Cerrito PB, McMasters KM: University of Louisville Breast Cancer Sentinel Lymph Node Study Group: predicting the status of the nonsentinel axillary nodes: a multicenter study. Arch Surg 2001, 136:563-568

27. Tan YY, Fan YG, Lu Y, Hwang S, Ewing C, Esserman L, Morita E, Treseler P, Leong SP: Ratio of positive to total number of sentinel nodes predicts nonsentinel node status in breast cancer patients. Breast J 2005, 11:248-253

28. Yu JC, Hsu GC, Hsieh CB, Sheu LF, Chao TY: Prediction of metastasis to non-sentinel nodes by sentinel node status and primary tumor characteristics in primary breast cancer in Taiwan. World J Surg 2005, 29:813-818

29. Govindarajan A, Ghazarian DM, McCready DR, Leong WL: Histological features of melanoma sentinel lymph node metastases associated with status of the completion lymphadenectomy and rate of subsequent relapse. Ann Surg Oncol 2006, 14:906-912

30. Imoto S, Ochiai A, Okumura C, Wada N, Hasebe T: Impact of isolated tumor cells in sentinel lymph nodes detected by immunohistochemical staining. Eur J Surg Oncol 2006, 32: 1175-1179

31. Schrenk P, Konstantiniuk P, Wölfl S, Bogner S, Haid A, Nemes $C$, Jagoutz-Herzlinger M, Redtenbacher S: Prediction of nonsentinel lymph node status in breast cancer with a micrometastatic sentinel node. Br J Surg 2005, 92:707-713 